\title{
HIV-associated synaptic degeneration
}

\author{
Wenjuan Ru and Shao-Jun Tang*
}

\begin{abstract}
Human immunodeficiency virus (HIV) infection induces neuronal injuries, with almost $50 \%$ of infected individuals developing HIV-associated neurocognitive disorders (HAND). Although highly activate antiretroviral therapy (HAART) has significantly reduced the incidence of severe dementia, the overall prevalence of HAND remains high. Synaptic degeneration is emerging as one of the most relevant neuropathologies associate with HAND. Previous studies have reported critical roles of viral proteins and inflammatory responses in this pathogenesis. Infected cells, including macrophages, microglia and astrocytes, may release viral proteins and other neurotoxins to stimulate neurons and cause excessive calcium influx, overproduction of free radicals and disruption of neurotransmitter hemostasis. The dysregulation of neural circuits likely leads to synaptic damage and loss. Identification of the specific mechanism of the synaptic degeneration may facilitate the development of effective therapeutic approaches to treat HAND.
\end{abstract}

\section{Introduction}

There are almost 37 million HIV-infected people worldwide, with over 1 million in U.S in 2015 (https:// www.hiv.gov/hiv-basics/overview/data-and-trends/statistics). No cure is currently available. HIV attacks the immune system, especially CD4 T cells, leading to immune dysfunction. Soon after the infection, HIV enters the central nervous system (CNS) and causes neurological dysfunction. Even with the effective anti-retroviral therapy that suppresses viral replication and transmission, about $70 \%$ of HIV patients still develop neurological complications [1]. Multiple neurological disorders are manifested in HIV patients.

HIV-associated neurocognitive disorder (HAND) is a common primary neurological disorder associated with HIV infection of the CNS. Patients with HAND often develop cognitive impairment, motor dysfunction and speech problems. Clinical severity of HAND ranges from asymptomatic neurocognitive impairment and mild neurocognitive disorder to HIV-associated dementia (HAD) [2]. Due to the success of HAART, HAD has declined, with a prevalence of less than $5 \%$ of HIV patient who are on the treatment [3]. However, the mild forms of HAND are still common and significantly affect a patient's quality of life.

\footnotetext{
* Correspondence: shtang@utmb.edu

Department of Neuroscience and Cell Biology, University of Texas Medical Branch, Galveston, TX 77555, USA
}

(c) The Author(s). 2017 Open Access This article is distributed under the terms of the Creative Commons Attribution 4.0 International License (http://creativecommons.org/licenses/by/4.0/), which permits unrestricted use, distribution, and reproduction in any medium, provided you give appropriate credit to the original author(s) and the source, provide a link to the Creative Commons license, and indicate if changes were made. The Creative Commons Public Domain Dedication waiver (http://creativecommons.org/publicdomain/zero/1.0/) applies to the data made available in this article, unless otherwise stated. HIV patients. With the improved survival of HIV patients on HAART, the prevalence of HIV-associated neuropathy has increased, with about $42 \%$ of HIV patients showing neuropathy symptoms [4]. The clinical symptoms include unusual sensation, numbness and severe pain. However, pathological analysis of autopsies indicate that almost all patients with AIDS develop peripheral neuropathy, including those who did not show clinical symptoms [5].

HIV-associated vacuolar myelopathy (VM) is commonly associated with late stages of HIV infection. Of AIDS patients, $20-55 \%$ exhibit symptoms of VM [6]. Vacuolization in dorsal and lateral tracts in the thoracic spinal cord is a common pathological characteristic. Patients with VM manifest progressive weakness of legs and sensory abnormalities, and VM may ultimately lead to paralysis of lower limbs [6].

In addition to HIV infection, anti-retroviral therapy may also contribute to neurological disorders. HAART is the current standard treatment for HIV infection. It is a customized combination of different classes of antiretroviral agents, including nucleoside reverse transcriptase inhibitors (NRTIs), non-nucleoside reverse transcriptase inhibitors, protease inhibitors, integrase inhibitors and entry inhibitors. For example, patients treated with NRTIs are prone to develop neuropathy and/or myopathy in a dosedependent manner [7-9]. A major side effect of protease inhibitors on the CNS is lipodystrophy syndrome, which is characterized by peripheral fat wasting and central 
adiposity [10]. NRTIs have also been linked to lipodystrophy [11]. HAART was also reported to increase the incidence of encephalitis [12] and induce neuropathy [13].

In this review, we will focus on HAND. In particular, we will critically consider the current understanding of HAND neuropathogenesis from three related aspects: the neuropathogenic underpinnings, the model systems for mechanistic studies, and potential mechanisms of HAND-associated synapse degeneration.

\section{Neuropathology of HAND \\ Early stages}

Although $70 \%$ of people with HIV have neuropathological abnormalities in the era of HAART [1], only a few studies have reported neuropathology in HIVinfected individuals before the onset of AIDS due to the limited availability of postmortem brains. Most HIV-1 patients remain neurologically unimpaired during early pre-AIDS stages. It generally takes 3 to 6 weeks to become seropositive after HIV infection, and this period is known as seroconversion. During seroconversion, 50$70 \%$ of HIV-infected people experience transient "acute HIV syndrome", such as symptomatic meningitis [14], encephalopathy $[15,16]$ or myelopathy [17]. Some clinicopathological studies revealed that the CNS entry of HIV-1 might also induce demyelination in the white matter during seroconversion $[18,19]$.

\section{Asymptomatic period}

After the seroconversion period, HIV infection enters a latency phase called the asymptomatic period, which usually lasts for 8-10 years. Neurological pathologies are noted during this stage, especially in the white matter, although the pathological changes are not consistent. Vascular inflammation is frequently observed in the white matter and basal ganglia, and microglial activation, astrocytosis and myelin pallor are observed in the white matter during this stage [20-22]. Although microglial activation is observed in the cerebral cortex [23], neuronal loss and astrocyte proliferation are rarely seen there [22].

\section{AIDS stage}

Autopsies found that $80-100 \%$ of AIDS patients had neuropathological changes in the CNS [24-27]. HIV- associated encephalitis (HIVE) was also observed in some patients at this stage. The neuropathological characteristics of HIVE include microglial nodules, multinucleated giant cells, reactive astrocytosis, microglial proliferation, myelin pallor, and infiltration of peripheral monocytes [28-31]. In contrast to the pre-AIDS stages, when neuronal loss is not seen, neuronal death is frequently observed in AIDS patients [32]. Significant neuronal loss has been reported in the frontal cortex [32-34]. Neuronal death via apoptosis occurs in AIDS patients
[35, 36]. Non-apoptotic neuronal injuries, including retraction of dendritic spines, dendritic pruning or aberrant sprouting, axonal disruption and synaptic degeneration, were also observed. Immunostaining analysis of postmortem brain tissues using synaptic and dendritic markers revealed dendritic beading, synaptic degeneration and dendritic spine loss in the brain of HIV patients [37-39]. Axonal injury indicated by elevated neurofilament protein in CSF is also detected in HIV patients [39-41]. Loss of synaptodendritic structures in HIV patients is correlated with reduced volume of neuropil and white matter $[41,42]$.

\section{Synaptic degeneration and HAND}

Multiple studies have been carried out to identify the neuropathological underpinnings of HAND. Both HIV encephalitis and neuronal loss are observed in the brain after HIV infection, and they appear to associate with severe dementia. However, they do not correlate well with milder forms of cognitive impairment [43]. HIV encephalitis occurs in some but not all HIV-infected individuals. Its presence and severity do not correspond to the degree of cognitive deficits [44-46]. In addition, different from other neurocognitive conditions such as Alzheimer's or Parkinson's diseases, the early dementing process in HIV patients is not associated with substantial neuronal apoptosis. Weis et al. reported that AIDS patients with clinical signs of progressive dementia showed no significant difference in neuronal densities compared to patients lacking dementia, indicating that neuronal loss was not causally linked to the development of dementia [33]. Nonetheless, synaptic alteration and degeneration in the brains of HIV patients appear to correlate well with the presence and severity of cognitive impairment [38, 47, 48]. Inhibition of synaptic degeneration may provide an attractive therapeutic target to prevent HAND pathogenesis.

\section{Animal models of HAND}

To investigate the neuropathogenic mechanism of HAND-related pathologies observed in human patients, relevant animal models are essential. Several animal models develop specific aspects of cognitive defects and neuropathological key features of HAND.

\section{Non-human primate models}

The simian immunodeficiency virus (SIV)-infected macaque is an established relevant model for studying the pathogenesis of HAND. In monkeys, SIV can enter the brain shortly after infection and causes brain abnormalities. SIV infection recapitulates the main features of immune response of HIV infection [49-53]. Additionally, HIV-associated neuropathologies in the brains of HIV patients are also developed in the SIV-infected macaque. 
For example, pre-synaptic damage was reported in SIVinfected macaques, as indicated by elevated levels of neuronal damage marker 14-3-3 protein in the CSF $[54,55]$. SIV-infected macaques developed various types of behavioral impairments, similar to those observed in HIV patients, as shown by a number of behavioral and neurophysiological testing modalities [56-60]. This model is particularly useful to study the pathogenesis of HAND in the era of HAART, because the infected macaque can be treated with HAART regimens to mimic the clinical settings [61]. It is also very helpful for the investigation of the synergized effects of drug abuse and HIV infection during neuropathogenesis [62-65]. In addition, because of the multi-time accessibility of CSF, plasma and CNS samples during the progression of infection, this model allows the investigation of the development of HAND through the progressive stages.

Although studies with SIV-infected macaques provide valuable insights into the pathogenesis of HIV infection, it is important to keep in mind that SIV and HIV are not the same. For example, CCR5-preferred HIV can gain the ability to use CXCR4 to enter into monocyte-derived macrophages [66, 67], while CCR5-preferred SIV uses other co-receptors such as CXCR6, GPR15 and GPR but not CXCR4 to enter host cells [68]. To address these limitations, simian-human immunodeficiency virus (SHIV) was constructed, in which the env gene of SIV was replaced by HIV-1 env. Therefore, the hybrid viruses are biologically more similar to HIV than SIV. Macaques infected with SHIV89.6P (CXCR4/CCR5 virus) developed encephalitis characterized by multinucleated giant cells, astrogliosis, microglial nodules, activated macrophages and astrocytes, and perivascular cuffing with mononuclear cells in the white matter [69]. CCR5 (R5)-tropic SHIVSF162P3N virus caused giant cell SIV encephalitis in approximately $30 \%$ of infected rhesus macaques that developed AIDS [70]. Giant cell SIV encephalitis lesions included white matter damage, necrosis, and astroglial and microglial activation [70]. SHIVKU, a CXCR4 virus, also could productively replicate in the CNS of rhesus macaques and caused pathological changes [71-73]. Despite the significant contributions of non-human primate models to understanding HIV-1-associated neuropathogenesis, these models are limited by their availability and high cost of maintenance.

\section{Rodent models}

For reasons that are not completely defined, rodents cannot be productively infected by HIV-1. To circumvent this drawback, transgenic mice are generated to express HIV-1 proteins such as the envelope protein gp120 and the transactivator of transcription (Tat), both of which are neurotoxic. In a gp120 transgenic mouse (gp120Tg) model, the gp120 transgene is controlled by the glial fibrillary acidic protein promoter, and thus gp120 is restricted to astrocytes [74]. The release of astrocytically expressed gp120 protein can affect nearby neurons. Confocal imaging of brain sections labeled with dendritic and synaptic markers revealed the dendritic vacuolization, loss of dendritic spines and presynaptic termini in the neocortex and the hippocampus [74]. This gp120Tg mouse also showed reaction of glial cells [74] and impaired proliferation and differentiation of neuronal progenitor cells $[75,76]$. Additionally, aging (12 months) gp120Tg mice developed deficits in motor and cognitive performance [74, 77].

In another transgenic mouse model, the Tat transgene is expressed in astrocytes in a Dox-regulated manner [78]. The inducible expression of Tat provides the ability to study the temporal effect of Tat released from astrocytes. This transgenic mouse displays degeneration of neuronal dendrites, neuron death, astrocytosis and enhanced infiltration of activated monocytes and $\mathrm{T}$ lymphocytes, and these alterations are largely observed in the cerebellum and cortex [78]. Other studies described more subtle neuronal injuries such as spine loss and synaptic degeneration in hippocampal pyramidal CA1 neurons and striatal neurons [79-81]. The Tat transgenic mice develop impairments in spatial memory and novel object recognition memory $[78,81,82]$.

Transgenic mice with full-length [83, 84] or gag-poldeleted HIV-1 genomic DNA [85] have been reported. The integrated HIV-1 genome in the transgenic mouse somewhat resembles HIV-1 provirus. In addition, the transgenic HIV-1 genome has the potential to express multiple HIV-1 proteins. These strengths of this transgenic strategy, however, also complicate the result interpretation for determining the causal relationship between specific HIV-1 proteins and observed phenotypes. Despite low levels of viral protein expression, the fulllength transgenic mouse model shows impaired nerve conduction, axonal degeneration and decreased nerve fiber density in the peripheral nervous system. They are also impaired in motor function [83], and show hyperreaction of microglia and astrocytes $[84,86]$.

The HIV-1 transgenic rat has been studied by multiple groups as a model of HIV-associated neurological diseases. It contains a gag-pol-deleted HIV-1 genome that is controlled by the viral promoter. Since without gag and pol genes that are responsible for viral replication, it cannot produce infectious virions [87]. This rat model expresses multiple viral proteins. In particular, the expression of Tat, gp120, nef and vif RNAs show age-dependent profiles, shifting from peripheral immune organs to the CNS at 10-11 months of age. These features of HIV-1 gene expression indicate that the HIV-1 transgenic rats can model specific aspects of HIV-1-infected 
individuals on HAART [88]. The 7-to-9-month-old animals show up-regulated expression of neuroinflammation markers such as interleukin-1 $\beta$ (IL-1 $\beta$ ), tumor necrosis factor $\alpha$ (TNF- $\alpha)$ and microglial/macrophage marker CD11b [89], which may contribute to the observed synapto-dendritic injury [89]. The transgenic rats develop spatial learning deficits $[90,91]$ and are impaired in motor performance [92].

The HIV-1 transgenic rodent models described above provide useful tools to study the contribution of viral proteins to the pathogenesis of HAND. However, they have significant limitations. Foremost, they do not acquire HIV-1 infection and thus cannot faithfully model the initial infection stages or the AIDS progression, which are key events associating with HAND development. Understandably, efforts continue to create additional rodent models to mimic HIV infection. One strategy is to introduce human HIV-1 receptors and coreceptors in transgenic rodents [93]. However, it appears that HIV-1 replication was defective in CD4 or CCR5 transgenic rodents $[94,95]$.

Potash et al. designed a creative approach to generate a novel mouse model of HIV-1 infection. They constructed a chimeric HIV-1 virus by replacing the HIVgp120 coding region with the gp80 envelope gene from the ectotropic murine leukemia virus. This chimeric virus, called EcoHIV, can enter to the host cells by binding to cationic amino acid transpoter-1 (mCAT) [96]. Despite the widespread expression of mCAT in the mouse tissues, persistent infection seems to be restricted to splenic lymphocytes, peritoneal macrophages and brain $[96,97]$. EcoHIV infection by stereotactic inoculation into the mouse basal ganglia caused pre-clinical brain pathology such as microglia and astrocyte activation $[96,98]$. However, the lack of gp120 in the chimeric virus presents specific limitations in this model. First, it is unclear to what degree the chimeric virus mimics the HIV-1 infection. For example, it may not target the same populations of cells as HIV-1. In addition, because gp120 is a major HIV-1 neurotoxic protein, this model may not recapitulate some of the neuropathological phenotypes related to HAND.

HIV-infected humanized mice are the exciting new rodent models. One strategy is to generate humanized mice with CNS HIV infection by direct injection of infected human cells. HIV-infected human monocytederived macrophages or HIV-infected human microglia cells are injected into the brain of severe combined immunodeficiency deficient (SCID) mice $[99,100]$ or reconstituted SCID mice with human peripheral blood leukocytes (PBLs) (huPBL/SCID) [101, 102]. SCID and huPBL/SCID mice with the infected human cells recapitulate the several neurological pathologies observed in HIV patients with HIVE, including multinucleated giant cells, astrogliosis, microglial activation and neuronal damage [99-102]. The SCID-HIVE mouse model also develops cognitive deficits. Morris water maze tests revealed their learning and memory impairments, regardless of HAART treatment [103]. Using these models, isolate-specific cognitive deficits and neuropathology were reported. Intracranial injection of macrophages infected with a clade B HIV-1 isolate (HIV-1(ADA)) into SCID mice caused worse performance in cognitive tests and more severe pathological changes than a clade $\mathrm{C}$ HIV-1 isolate (HIV-1(Indie-C1)) [104].

Another strategy to generate humanized mice is systemic transplantation of human hematopoietic stem cells $\left(\mathrm{CD}_{3}{ }^{+}\right.$cells) or adult human peripheral blood mononuclear cells into various immunodeficient mice so that the mice host the human target cells for HIV-1 infection [105-110]. Various neuropathologies were reported in HIV-infected humanized mouse models. For example, $\mathrm{NOD} / \mathrm{SCID}-\mathrm{IL}-2 \mathrm{R} \gamma_{\mathrm{c}}^{\text {nul }}$ (NSG) mice with engrafted human CD34+ stem cells (NSG-hCD34+) developed a functional human immune system containing $\mathrm{T}$ lymphocytes, monocytes and macrophages could be efficiently infected with HIV [111-114]. Neuronal and synaptic damages were detected by immunohistochemical staining of various neuronal and synaptic markers such as microtubule associated protein-2, neurofilament and synaptophysin. The neuropathologies appeared to correlate with glial cell activation $[112,113]$. The animals also showed memory deficits and persistent anxiety $[112,113]$. Although less used for CNS infection, other humanized mouse models (e.g. humanized bone marrow/liver/thymus mouse models) have been used for studies on HIV pathogenesis, transmission, replication and prevention.

\section{In vitro models}

Primary neuron cultures are useful for studying the neurotoxicity of HIV-1 proteins such as gp120 and Tat. Confocal imaging of cultured rat hippocampal neurons revealed that gp120 application caused a dramatic decrease in the number of synapses [115]. Similarly, Tat treatment also induced synaptic loss [116-118]. In addition, gp120 was shown to cause dendritic damage in human primary neurons $[115,119]$. Mixed primary cultures that have neurons and glia cells provide an in vitro experimental setting for investigating the interaction between neurons and other cell types (e.g. microglia and astrocytes) during the HIV-induced neuropathogenesis.

\section{Mechanisms of synaptic degeneration induced by HIV-1 infection}

As HIV-1 cannot infect neurons, HIV-associated synaptic degeneration is likely a bystander effect of the infected cells, including perivascular macrophages, 
microglia and astrocytes. The infected cells may elicit neurodegenerative responses by releasing viral proteins and other toxic factors such as chemokines and cytokines. The neurotoxins may induce arrays of cellular and molecular cascades that eventually lead to synaptic loss, including $\mathrm{Ca}^{2+}$ overload, energy hemostasis disturbance, neurotransmitter (e.g. glutamate) metabolism perturbation, oxidative stresses and excitatory toxicity. In the following sections, we discuss potential mechanisms regulating HIV-induced synaptic degeneration (Fig. 1).

\section{Neurotoxicity of viral proteins}

Viral proteins, particularly gp120 and Tat, are released from infected microglia/macrophages and astrocytes. Gp120 is thought to induce synaptic degeneration via multiple mechanisms. One suggested pathway is glutamate receptor activation-mediated excitotoxicity such as the hyperactivation of $\mathrm{N}$-methyl-D-aspartate receptor (NMDAR) and its associated excessive $\mathrm{Ca}^{2+}$ influx [120]. Gp120 can activate NMDARs by binding to their glycine binding sites [121]. Gp120 may also enhance synaptic activity by potentiating the phosphorylation and synaptic trafficking of NMDARs [122]. In addition to stimulating
NMDARs, gp120 can bind to its chemokine co-receptor CXCR4 or CCR5 on the neurons to mediate neuronal damage [123, 124]. M-tropic HIV-1 strains preferably bind to CCR5 [125-127], and T-tropic strains use CXCR4 to gain entry into the cells [128]. After binding to its co-receptor, gp120 may facilitate NMDAR activation and intracellular $\mathrm{Ca}^{2+}$ increase to induce neuronal damage [129-134] and/or activate signaling cascacades (e.g. ERK and p38 MAPK signaling pathways) that are asssociated with cell damage and death [135-137]. Alternatively, gp120 might cause neurotoxicity via indirect mechanisms. Gp120 can potentiate NMDAR activity by inducing release of proinflammatory cytokines from glial cells $[138,139]$. For instance, after binding to the interleukin-1 receptor, IL-1 $\beta$ can stimulate the phosphorylation of NR2B at tyrosine 1472 to potentiate NMDAR activation [138]. In addition, gp120 may cause glial dysfunction and impair extracellular glutamate reuptake. Accumulated extracellular glutamate and NMDAR hyperactivation will induce synaptic damage [140-143]. Furthermore, the neurotoxicity of gp120 may be mediated by down-regulating release of neurotrophic factors (such as BDNF) from activated glia cells [144-148].

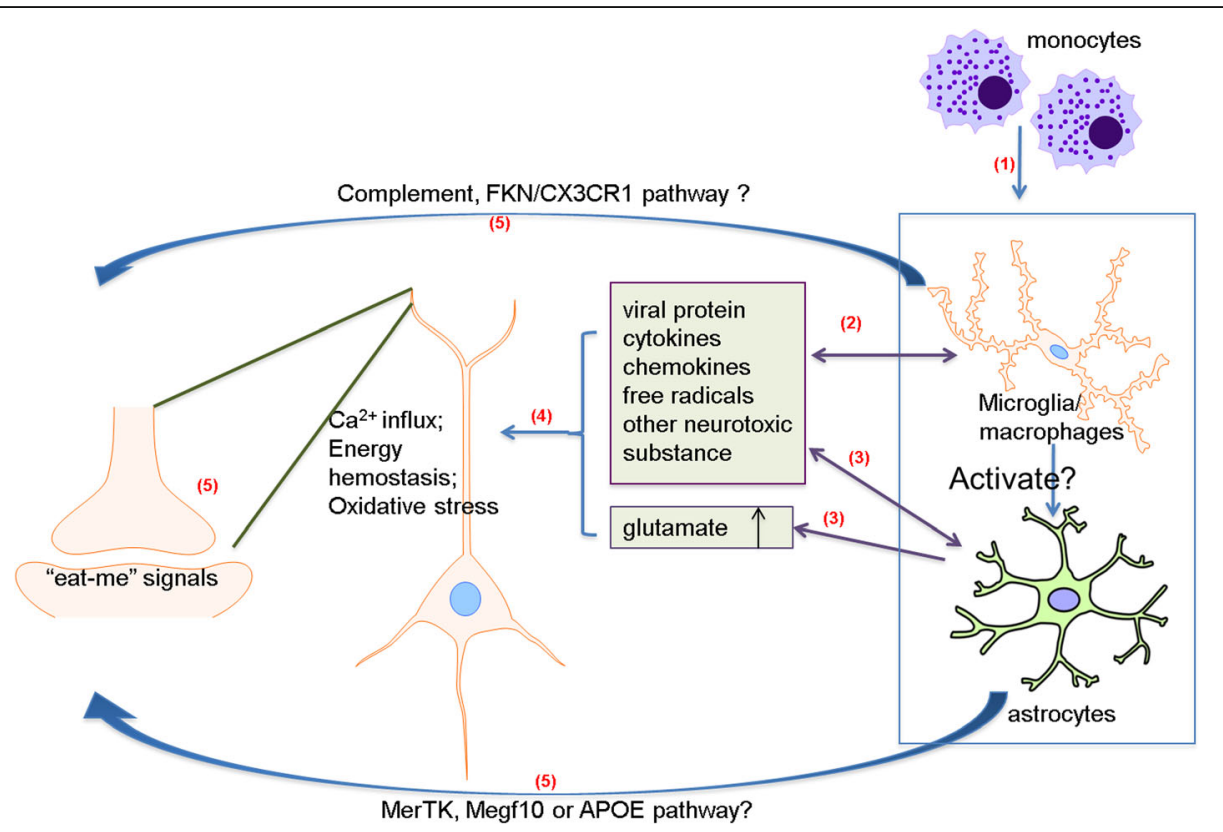

Fig. 1 Potential mechanisms of HIV-induced synaptic degeneration. (1) HIV-1 infection of the CNS initiates from transmigration of HIV-1-infected peripheral blood monocytic cells/macrophages across the blood-brain barrier (BBB). Subsequently, microglia and astrocytes become infected and reactivated. (2) The immune-activated and HIV-1-infected microglia/macrophages release viral proteins (e.g. gp120, Tat, Vpr), cytokines (e.g. IL-1 $\beta$, IL-6, TNF-a), chemokines (e.g. CXCL12, MCP1) and other neurotoxic factors. (3) Infected/reactivated astrocytes can also release neurotoxic substances and pathogenically enhance synaptic activity with increased transmitter release and impaired glutamate re-uptake. (4) The released neurotoxins and extracellular glutamate can cause excessive $\mathrm{Ca}^{2+}$ influx, disturbance of energy metabolism and production of reactive oxidative species, which then lead to the disruption of normal neuronal function. On the other hand, the released viral proteins, cytokines, chemokines and free radicals can activate more glial cells and macrophages. (5) These damaged neurons may mark the abnormal synapses with some kind of "eat-me" signals, which can be recognized and eliminated by microglia and/or astrocytes through phagocytotic pathways such as the complementary and FKN/CX3CR1 pathways in microglia or the MerTK, Megf10 and APOE pathway in astrocytes 
By binding to the low-density lipoprotein receptorrelated protein (LRP), Tat protein can cause NMDAR activation, excessive $\mathrm{Ca}^{2+}$ influx $[118,149-151]$ and mitochondrial dysfunction [152, 153]. These Tat effects trigger downstream events that contribute to synaptic loss, including the activation of the ubiquitin-proteasome pathway $[116,117]$, the disturbance of energy metabolism [154] and the production of reactive oxidative species [152, 155]. Tat also stimulates glial cells and macrophages to release cytokines, chemokines and other neurotoxic factors that cause neuronal injury [156-158].

\section{Neuroinflammation}

HIV-1 enter the CNS soon after peripheral infection of blood monocytes and circulating T cells, mainly through a "Trojan horse" mechanism [159] as well as other routes such as "transcytosis" or infection of BBB endothelial cells [160-164]. The viral proteins, inflammatory cytokines and chemokines released from infected and/or activated cells can lead to disruption of BBB integrity and hence exacerbation of the entry of infected cells [165]. As a key component in the BBB structure, astrocytes that become infected can directly cause the increase of BBB permeability [166].

Microglia and perivascular macrophages are CNSresident immunocompetent cells that can be productively infected by HIV-1. After HIV infection, substantial pro-inflammatory cytokines (e.g. TNF- $\alpha$, IL- 6 and IL-1 $\beta$ ) are released from infected/reactivated microglial cells/ macrophages [138, 139, 167, 168]. Cytokines in peripheral circulation may also traffic to the CNS [169-171]. The cytokines are elevated in the CSF of HIV patients with cognitive impairments [172, 173]. They may contribute to the pathogenesis of synaptic degeneration via multiple pathways, including NMDAR hyperactivation. For instance, TNF- $\alpha$ and IL-1 $\beta$ can stimulate L-cysteine release from macrophages, which then activates NMDARs to cause neuronal damage [174]. In addition, cytokines may also induce synaptic abnormalities by aberrantly activating cytokine receptors [175-177]. After binding to its receptors on neurons, TNF- $\alpha$ activates multiple pathways that are implicated in neuronal damage, including the nuclear factor-kappa B (NF- $\kappa \mathrm{B})$, ERK, p38 MAPK, the c-Jun N-terminal kinase, and caspase pathways [133, 178].

HIV-infected microglia and macrophages may also release chemokines, which can stimulate neurons via chemokine receptors to induce synaptic degeneration. For example, CXCL12/SDF- $1 \alpha$ is elevated in the brain and CSF of HIV patients with HAD $[179,180]$. By binding to its receptors, CXCL12 can function as either neuroprotective or neurotoxic mediator $[148,181,182]$. When CXCL12 is cleaved, it switches its preferred receptor from CXCR4 to CXCR3, leading to enhanced neurotoxic effects [183]. Another chemokine, CXCL10, promotes neuron injury by stimulating $\mathrm{Ca}^{2+}$ flux [184-186]. Chemokines may also cause neuronal damage by inducing monocyte infiltration. For instance, monocyte chemoattractant protein-1 (MCP1, a.k.a. CCL2) increases in the CSF of HIV patients with cognitive impairment [187], and the MCP-1 increase is implicated in neuronal injury by promoting migration and infiltration of monocytes/macrophages [188-191]. The neuron-released chemokine fractalkine (FKN; a.k.a. CX3CL1), which is also up-regulated in HIV patients [192-195] and has been implicated in HIVassociated dementia [196-198], may also modulate monocyte migration and neuron damage [195, 199-201].

Besides cytokines and chemokines, reactive microglia can also release other neurotoxic substances such as excitatory amino acids, platelet-activating factor and free radicals [202-206]. These neurotoxins may cause NMDAR-mediated excitotoxicity by excessive $\mathrm{Ca}^{2+}$ influx and oxidative stress.

Reactive microglia assume diverse phenotypes, which are roughly categorized into the "classical" activation (M1) and "alternative" activation (M2) phenotypes. M1 microglia secrete pro-inflammatory cytokines (e.g. TNF$\alpha$, IL-1 $\beta$, interleukin-6 (IL-6)) and reactive oxygen species [207-209], which are implicated in synaptic damage. On the other hand, M2 microglia play a role in repairing neuronal injuries and clearing debris, and they produce anti-inflammatory cytokines and substances such as IL-10, arginase-1 (Arg-1), chitinase 3-like 3 (Chi3l3) and transforming growth factor- $\beta$ (TGF- $\beta$ ) to facilitate the repair processes [207-209]. Therefore, M1-M2 polarization may play a crucial role in determining the potential neurotoxic or neuroprotective activity of microglia in neurodegeneration disorders [210]. It is currently unknown if dysregulation of M1/M2 polarization of microglia is involved in the pathogenesis of HIV-associated synaptic degeneration.

Although only a small population of astrocytes can be infected by HIV [211-214], the infected astroglia play a critical role in the HIV-associated synaptic injury $[213,215]$. Astrocytes are a potentially important reservoir for HIV persistence. In autopsy brain tissues of HIV patients, up to $20 \%$ of astrocytes contain integrated HIV-1 [214]. The infected astrocytes produce and secrete viral protein such as gp120, Tat, Vpr, Rev. and Nef, although viral replication is restricted [3, 216-219]. Tat and gp120 can activate astrocytes to produce proinflammatory cytokines such as TNF- $\alpha$, IL- 6 and IL- $1 \beta$ $[168,220]$, the chemokine CCL5 [221], and neurotoxic nitric oxide (NO) [222], which, as described above, can cause synaptic damage. More recent studies showed that HIV-infected astrocytes could spread the toxic signals to neighboring neurons or un-infected glial cells through gap junctions [223]. The infected astrocytes also increase secretion of CCL2 and glutamate, which 
may contribute to the dysregulation of the integrity of the $\mathrm{BBB}$ as well as defects in monocyte recruitment and immune responses in the CNS [166, 223]. In addition, HIV-infected and/or reactivated astrocytes are probably impaired for glutamate re-uptake, resulting in increased extracellular glutamate and excitotoxicityinduced synaptic degeneration [224-226].

\section{A role of glia-mediated phagocytosis of synapses?}

The discovery of microglial phagocytosis in developmental synaptic pruning [227-229] presents an intriguing possibility of similar mechanisms in synaptic degeneration induced by HIV-1 infection. Microglial phagocytosis is mediated by the classical complement system [229, 230]. More recent work indicates that this microglia-based mechanism is implicated in synaptic loss in Alzheimer's disease [229, 231] and West Nile virus-induced synaptic loss [232]. Although a role of the complement system was suggested in the immune defense for HIV infection [233, 234], little is known about its involvement in HIV-associated neurodegeneration in the CNS. Complement proteins $\mathrm{C} 1 \mathrm{q}$ and $\mathrm{C} 3$ are significantly increased in the brains and CSF of HIV patients, and the increase is associated with the up-regulation of the neuronal injury marker neurofilament protein in the CSF and with cognitive impairments [235]. It will be interesting to investigate if complement-mediated microglial phagocytosis contributes to HIV-associated synaptic degeneration. Moreover, the FKN/CX3CR1 pathway also regulates the phagocytosis of microglia [236-238], but its potential contribution to HIV-induced synaptic degeneration has not been tested.

Astrocytes have numerous processes that intimately interact with synapses and monitor synaptic activity. Recent studies indicate that astrocytes can eliminate synapses by phagocytosis [239-241]. Astrocytes express critical regulators of phagocytotic pathways, including Megf10 and MerTK, which play important roles during elimination of synapses in the developing and adult brain [239]. In addtion, the synaptic phagocytic capacity of astrocytes is highly controlled by an APOE isoform in Alzheimer's disease brains. APOE2 enhances the phagocytic activity of astrocytes; whereas $\mathrm{APO} 4$ decreases the rate of synaptic phagocytosis by astrocytes [242]. It is intriguing to conceive that astrocyte dysfunction might contribute to pathogenic synaptic degeneration in the neuropathogenesis of HAND.

\section{Conclusion}

It is clear that HIV-associated synaptic degeneration is a result of cascades of neuropathogenic processes initiated by HIV-1 infection (and often in combination with related comorbidities). The progression of the pathogenesis is determined by the interaction between HIV-1 and the host. The high prevalence of HAND in patients with HAART, which successfully suppresses HIV-1 replication, indicates that intact virions are probably not the major pathogenic agent. Instead, individual HIV-1 toxic proteins such as gp120 and Tat released from infected cells in the CNS may play a major role in inducing the synaptic degeneration. This view posits an interesting and relevant possibility that infected cells that do not productively assemble infective virions, thanks to HAART, may still synthesize pathogenic HIV-1 proteins. The scenario of replication-independent production of HIV-1 protein is superficially counterintuitive, and the underlying mechanism is still poorly understood. Mounting evidence is documenting the neurotoxic effects of individual HIV-1 proteins. Published studies have mainly focused on specific HIV-1 proteins such as gp120 and Tat in different experimental systems, and they have found that more than one HIV-1 protein may elicit complicated molecular pathways that potentially contribute to synaptic degeneration. When these proteins are co-released from the infected cells in the CNS, they likely act in conjunction to cause synaptotoxicity. The conceived interaction of multiple HIV-1 proteins would dramatically increase the complexity of the pathogenic cascades. At the cellular level, in addition to the excitotoxicity from direct stimulation of neurons, reactive microglia and astrocytes likely also attack the neurons at synaptic regions to contribute to the concerted processes of synaptic degeneration. These intrinsically complicating interactions at the molecular and cellular levels in vivo indicate a potential heterogeneity of the pathogenesis among HIV patients, and synaptic degeneration may result from different molecular and cellular pathways elicited by HIV infection in different patients. These conceived complexities and heterogeneity present a daunting task for defining the relevant pathogenic mechanisms in patients for years to come.

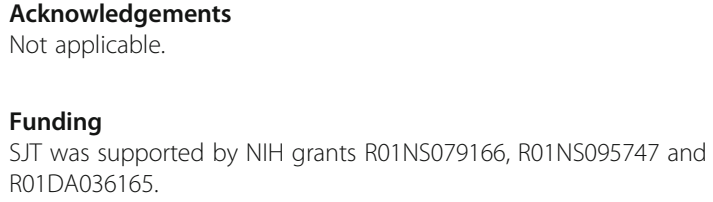

Availability of data and materials

Not applicable.

Authors' contributions

WR and SJT wrote the manuscript. Both authors read and approved the final manuscript.

Ethics approval and consent to participate Not applicable.

Consent for publication Not applicable. 


\section{Competing interests}

The authors declare that they have no competing interests.

\section{Publisher's Note}

Springer Nature remains neutral with regard to jurisdictional claims in published maps and institutional affiliations.

\section{Received: 20 March 2017 Accepted: 18 August 2017} Published online: 29 August 2017

\section{References}

1. Sacktor N. The epidemiology of human immunodeficiency virus-associated neurological disease in the era of highly active antiretroviral therapy. J Neuro-Oncol. 2002:8(Suppl 2):115-21.

2. Antinori A, Arendt G, Becker JT, Brew BJ, Byrd DA, Cherner M, Clifford DB, Cinque P, Epstein LG, Goodkin K, et al. Updated research nosology for HIVassociated neurocognitive disorders. Neurology. 2007;69:1789-99.

3. Saylor D, Dickens AM, Sacktor N, Haughey N, Slusher B, Pletnikov M, Mankowski JL, Brown A, Volsky DJ, McArthur JC. HIV-associated neurocognitive disorder - pathogenesis and prospects for treatment. Nat Rev Neurol. 2016;12:309.

4. Smyth K, Affandi JS, MCArthur JC, Bowtell-Harris C, Mijch AM, Watson K, Costello K, Woolley IJ, Price P, Wesselingh SL, Cherry CL. Prevalence of and risk factors for HIV-associated neuropathy in Melbourne, Australia 1993-2006. HIV Med. 2007:8:367-73.

5. Cornblath DR, MCArthur JC. Predominantly sensory neuropathy in patients with AIDS and AIDS-related complex. Neurology. 1988;38:794-6.

6. Di Rocco A, Simpson DM. AIDS-associated vacuolar myelopathy. AIDS Patient Care STDs. 1998;12:457-61.

7. Bozzette SA, Santangelo J, Villasana D, Fraser A, Wright B, Jacobsen C, Hayden E, Schnack J, Spector SA, Richman DD. Peripheral nerve function in persons with asymptomatic or minimally symptomatic HIV disease: absence of zidovudine neurotoxicity. J Acquir Immune Defic Syndr. 1991;4:851-5.

8. Dalakas MC, IIla I, Pezeshkpour GH, Laukaitis JP, Cohen B, Griffin JL. Mitochondrial myopathy caused by long-term zidovudine therapy. N Engl J Med. 1990:322:1098-105

9. Jay C, Ropka M, Dalakas MC. The drugs 2',3'-dideoxyinosine (ddl) and 2',3'dideoxycytidine ( $\mathrm{ddC}$ ) are safe alternatives in people with AIDS with zidovudine-induced myopathy. J Acquir Immune Defic Syndr. 1994;7:630-1.

10. Carr A, Samaras K, Burton S, Law M, Freund J, Chisholm DJ, Cooper DA. A syndrome of peripheral lipodystrophy, hyperlipidaemia and insulin resistance in patients receiving HIV protease inhibitors. AIDS. 1998;12:F51-8.

11. Carr A, Miller J, Law M, Cooper DA. A syndrome of lipoatrophy, lactic acidaemia and liver dysfunction associated with HIV nucleoside analogue therapy: contribution to protease inhibitor-related lipodystrophy syndrome. AIDS. 2000;14:F25-32.

12. Langford TD, Letendre SL, Larrea GJ, Masliah E. Changing patterns in the neuropathogenesis of HIV during the HAART era. Brain Pathol. 2003;13:195-210.

13. Maschke M, Kastrup O, Esser S, Ross B, Hengge U, Hufnagel A. Incidence and prevalence of neurological disorders associated with HIV since the introduction of highly active antiretroviral therapy (HAART). J Neurol Neurosurg Psychiatry. 2000;69:376-80.

14. Ho DD, Sarngadharan MG, Resnick L, Dimarzoveronese F, Rota TR, Hirsch MS. Primary human T-lymphotropic virus type III infection. Ann Intern Med. 1985;103:880-3.

15. Carne CA, Tedder RS, Smith A, Sutherland S, Elkington SG, Daly HM, Preston FE, Craske J. Acute encephalopathy coincident with seroconversion for antiHTLV-III. Lancet. 1985:2:1206-8.

16. Nzwalo H, Añón RP, Àguas MJ. Acute encephalitis as initial presentation of primary HIV infection. BMJ Case Rep. 2012;2012

17. Denning DW, Anderson J, Rudge P, Smith H. Acute myelopathy associated with primary infection with human immunodeficiency virus. Br Med J (Clin Res Ed). 1987:294:143-4.

18. Jones HR, Ho DD, Forgacs P, Adelman LS, Silverman ML, Baker RA, Locuratolo P. Acute fulminating fatal leukoencephalopathy as the only manifestation of human immunodeficiency virus infection. Ann Neurol. 1988:23:519-22

19. Gray F, Chimelli L, Mohr M, Clavelou P, Scaravilli F, Poirier J. Fulminating multiple sclerosis-like leukoencephalopathy revealing human immunodeficiency virus infection. Neurology. 1991;41:105-9.
20. Gray F, Lescs MC, Keohane C, Paraire F, Marc B, Durigon M, Gherardi R. Early brain changes in HIV infection: neuropathological study of 11 HIV seropositive, non-AIDS cases. J Neuropathol Exp Neurol. 1992;51:177-85.

21. An SF, Ciardi A, Giometto B, Scaravilli T, Gray F, Scaravilli F. Investigation on the expression of major histocompatibility complex class II and cytokines and detection of HIV-1 DNA within brains of asymptomatic and symptomatic HIV-1-positive patients. Acta Neuropathol. 1996;91:494-503.

22. Gray F, Scaravilli F, Everall I, Chretien F, An S, Boche D, Adle-Biassette H, Wingertsmann L, Durigon M, Hurtrel B, et al. Neuropathology of early HIV-1 infection. Brain Pathol. 1996:6:1-15.

23. Sinclair E, Gray F, Ciardi A, Scaravilli F. Immunohistochemical changes and $P C R$ detection of HIV provirus DNA in brains of asymptomatic HIV-positive patients. J Neuropathol Exp Neurol. 1994:53:43-50.

24. Kanzer MD. Neuropathology of AIDS. Crit Rev Neurobiol. 1990;5:313-62.

25. Anders $\mathrm{KH}$, Guerra WF, Tomiyasu U, Verity MA, Vinters HV. The neuropathology of AIDS. UCLA experience and review. Am J Pathol. 1986;124:537-58.

26. Gray F, Geny C, Lionnet F, Dournon E, Fenelon G, Gherardi R, Poirier J. Neuropathologic study of 135 adult cases of acquired immunodeficiency syndrome (AIDS). Ann Pathol. 1991;11:236-47.

27. Navia BA, Cho ES, Petito CK, Price RW. The AIDS dementia complex: II. Neuropathology. Ann Neurol. 1986;19:525-35.

28. Tauber SC, Staszewski O, Prinz M, Weis J, Nolte K, Bunkowski S, Brück W, Nau R. HIV encephalopathy: glial activation and hippocampal neuronal apoptosis, but limited neural repair. HIV Med. 2016;17:143-51.

29. Gelman BB. Diffuse microgliosis associated with cerebral atrophy in the acquired immunodeficiency syndrome. Ann Neurol. 1993;34:65-70.

30. Budka H. Multinucleated giant cells in brain: a hallmark of the acquired immune deficiency syndrome (AIDS). Acta Neuropathol. 1986;69:253-8.

31. Budka H. Neuropathology of human immunodeficiency virus infection. Brain Pathol. 1991:1:163-75.

32. Adle-Biassette H, Levy Y, Colombel M, Poron F, Natchev S, Keohane C, Gray F. Neuronal apoptosis in HIV infection in adults. Neuropathol Appl Neurobiol. 1995;21:218-27.

33. Weis S, Haug $H$, Budka H. Neuronal damage in the cerebral cortex of AIDS brains: a morphometric study. Acta Neuropathol. 1993;85:185-9.

34. Ketzler S, Weis S, Haug H, Budka H. Loss of neurons in the frontal cortex in AIDS brains. Acta Neuropathol. 1990;80:92-4.

35. Garden GA, Budd SL, Tsai E, Hanson L, Kaul M, D'Emilia DM, Friedlander RM, Yuan J, Masliah E, Lipton SA. Caspase cascades in human immunodeficiency virus-associated neurodegeneration. J Neurosci. 2002:22:4015-24.

36. Shi B, De Girolami U, He J, Wang S, Lorenzo A, Busciglio J, Gabuzda D. Apoptosis induced by HIV-1 infection of the central nervous system. J Clin Invest. 1996;98:1979-90.

37. Masliah E, Heaton RK, Marcotte TD, Ellis RJ, Wiley CA, Mallory M, Achim CL, McCutchan JA, Nelson JA, Atkinson JH, Grant I. Dendritic injury is a pathological substrate for human immunodeficiency virus-related cognitive disorders. HNRC Group. The HIV Neurobehavioral Research Center. Ann Neurol. 1997;42:963-72.

38. Everall IP, Heaton RK, Marcotte TD, Ellis RJ, McCutchan JA, Atkinson JH, Grant I, Mallory M, Masliah E. Cortical synaptic density is reduced in mild to moderate human immunodeficiency virus neurocognitive disorder. HNRC Group. HIV Neurobehavioral Research Center. Brain Pathol. 1999;9:209-17.

39. Gisslén M, Rosengren L, Hagberg L, Deeks SG, Price RW. Cerebrospinal fluid signs of neuronal damage after antiretroviral treatment interruption in HIV-1 infection. AIDS Res Ther. 2005;2:6.

40. Hagberg L, Fuchs D, Rosengren L, Gisslén M. Intrathecal immune activation is associated with cerebrospinal fluid markers of neuronal destruction in AIDS patients. J Neuroimmunol. 2000;102:51-5.

41. Norgren N, Rosengren L, Stigbrand T. Elevated neurofilament levels in neurological diseases. Brain Res. 2003;987:25-31.

42. Grant I, Atkinson JH, Hesselink JR, Kennedy CJ, Richman DD, Spector SA, McCutchan JA. Evidence for early central nervous system involvement in the acquired immunodeficiency syndrome (AIDS) and other human immunodeficiency virus (HIV) infections. Studies with neuropsychologic testing and magnetic resonance imaging. Ann Intern Med. 1987;107:828-36.

43. Adle-Biassette $H$, Chrétien F, Wingertsmann L, Héry C, Ereau T, Scaravilli F, Tardieu M, Gray F. Neuronal apoptosis does not correlate with dementia in HIV infection but is related to microglial activation and axonal damage. Neuropathol Appl Neurobiol. 1999;25:123-33.

44. Wiley CA, Achim CL. Human immunodeficiency virus encephalitis and dementia. Ann Neurol. 1995;38:559-60. 
45. Brew BJ, Rosenblum M, Cronin K, Price RW. AIDS dementia complex and HIV-1 brain infection: clinical-virological correlations. Ann Neurol. 1995;38:563-70.

46. Cherner M, Masliah E, Ellis RJ, Marcotte TD, Moore DJ, Grant I, Heaton RK. Neurocognitive dysfunction predicts postmortem findings of HIV encephalitis. Neurology. 2002:59:1563-7.

47. Ellis R, Langford D, Masliah E. HIV and antiretroviral therapy in the brain: neuronal injury and repair. Nat Rev Neurosci. 2007;8:33-44.

48. Sá MJ, Madeira MD, Ruela C, Volk B, Mota-Miranda A, Paula-Barbosa MM. Dendritic changes in the hippocampal formation of AIDS patients: a quantitative Golgi study. Acta Neuropathol. 2004;107:97-110.

49. Roberts ES, Zandonatti MA, Watry DD, Madden LJ, Henriksen SJ, Taffe MA, Fox HS. Induction of pathogenic sets of genes in macrophages and neurons in NeuroAIDS. Am J Pathol. 2003;162:2041-57.

50. Roberts ES, Masliah E, Fox HS. CD163 identifies a unique population of ramified microglia in HIV encephalitis (HIVE). J Neuropathol Exp Neurol. 2004;63:1255-64.

51. Roberts ES, Huitron-Resendiz S, Taffe MA, Marcondes MC, Flynn CT, Lanigan CM, Hammond JA, Head SR, Henriksen SJ, Fox HS. Host response and dysfunction in the CNS during chronic simian immunodeficiency virus infection. J Neurosci. 2006;26:4577-85.

52. Fox HS. Virus-host interaction in the simian immunodeficiency virus-infected brain. J Neuro-Oncol. 2008;14:286-91.

53. Marcondes MC, Burdo TH, Sopper S, Huitron-Resendiz S, Lanigan C, Watry D, Flynn C, Zandonatti M, Fox HS. Enrichment and persistence of virus-specific CTL in the brain of simian immunodeficiency virus-infected monkeys is associated with a unique cytokine environment. J Immunol. 2007;178:5812-9.

54. Sharer LR, Baskin GB, Cho ES, Murphey-Corb M, Blumberg BM, Epstein LG. Comparison of simian immunodeficiency virus and human immunodeficiency virus encephalitides in the immature host. Ann Neurol. 1988;23(Suppl):S108-12.

55. Helke KL, Queen SE, Mankowski JL. 14-3-3 protein in CSF reflects SIVmediated pre-synaptic damage. Curr HIV Res. 2013;11:281-7.

56. Weed MR, Gold LH, Polis I, Koob GF, Fox HS, Taffe MA. Impaired performance on a rhesus monkey neuropsychological testing battery following simian immunodeficiency virus infection. AIDS Res Hum Retrovir. 2004;20:77-89.

57. Gold LH, Fox HS, Henriksen SJ, Buchmeier MJ, Weed MR, Taffe MA, HuitrónResendiz S, Horn TF, Bloom FE. Longitudinal analysis of behavioral, neurophysiological, viral and immunological effects of SIV infection in rhesus monkeys. J Med Primatol. 1998;27:104-12.

58. Marcondes MC, Flynn C, Huitron-Rezendiz S, Watry DD, Zandonatti M, Fox HS. Early antiretroviral treatment prevents the development of central nervous system abnormalities in simian immunodeficiency virus-infected rhesus monkeys. AIDS. 2009;23:1187-95.

59. Horn TF, Huitron-Resendiz S, Weed MR, Henriksen SJ, Fox HS. Early physiological abnormalities after simian immunodeficiency virus infection. Proc Natl Acad Sci U S A. 1998;95:15072-7.

60. Weed MR, Hienz RD, Brady JV, Adams RJ, Mankowski JL, Clements JE, Zink MC. Central nervous system correlates of behavioral deficits following simian immunodeficiency virus infection. J Neuro-Oncol. 2003;9:452-64.

61. Zink MC, Brice AK, Kelly KM, Queen SE, Gama L, Li M, Adams RJ, Bartizal C, Varrone J, Rabi SA, et al. Simian immunodeficiency virus-infected macaques treated with highly active antiretroviral therapy have reduced central nervous system viral replication and inflammation but persistence of viral DNA. J Infect Dis. 2010;202:161-70.

62. Hollenbach R, Sagar D, Khan ZK, Callen S, Yao H, Shirazi J, Buch S, Jain P. Effect of morphine and SIV on dendritic cell trafficking into the central nervous system of rhesus macaques. J Neuro-Oncol. 2014;20:175-83.

63. Bokhari SM, Hegde R, Callen S, Yao H, Adany I, Li Q, Li Z, Pinson D, Yeh HW, Cheney PD, Buch S. Morphine potentiates neuropathogenesis of SIV infection in rhesus macaques. J Neurolmmune Pharmacol. 2011;6:626-39.

64. Marcario JK, Pendyala G, Riazi M, Fleming K, Marquis J, Callen S, Lisco SJ, Fowler SC, Cheney PD, Buch SJ. Effects of morphine on behavioral task performance in SIV-infected rhesus macaques. J Neurolmmune Pharmacol. 2016;11:348-57.

65. Marcondes MC, Flynn C, Watry DD, Zandonatti M, Fox HS. Methamphetamine increases brain viral load and activates natural killer cells in simian immunodeficiency virus-infected monkeys. Am J Pathol. 2010;177:355-61.

66. Gorry PR, Bristol G, Zack JA, Ritola K, Swanstrom R, Birch CJ, Bell JE, Bannert N, Crawford K, Wang H, et al. Macrophage tropism of human immunodeficiency virus type 1 isolates from brain and lymphoid tissues predicts neurotropism independent of coreceptor specificity. J Virol. 2001;75:10073-89.
67. Gray L, Roche M, Churchill MJ, Sterjovski J, Ellett A, Poumbourios P, Sherieff S, Sheffief S, Wang B, Saksena N, et al. Tissue-specific sequence alterations in the human immunodeficiency virus type 1 envelope favoring CCR5 usage contribute to persistence of dual-tropic virus in the brain. J Virol. 2009;83:5430-41.

68. Riddick NE, Hermann EA, Loftin LM, Elliott ST, Wey WC, Cervasi B, Taaffe J, Engram JC, Li B, Else JG, et al. A novel CCR5 mutation common in sooty mangabeys reveals SIVsmm infection of CCR5-null natural hosts and efficient alternative coreceptor use in vivo. PLoS Pathog. 2010;6:e1001064.

69. Buch S, Pinson D, Hou Y, Adany I, Li Z, Mukherjee S, Jia F, Mackay G, Silverstein P, Kumar A, Narayan O. Neuropathogenesis of chimeric simian human immunodeficiency virus infection in rhesus macaques. J Med Primatol. 2000;29:96-106.

70. Harbison C, Zhuang K, Gettie A, Blanchard J, Knight H, Didier P, ChengMayer C, Westmoreland S. Giant cell encephalitis and microglial infection with mucosally transmitted simian-human immunodeficiency virus SHIVSF162P3N in rhesus macaques. J Neuro-Oncol. 2014;20:62-72.

71. Raghavan R, Stephens EB, Joag SV, Adany I, Pinson DM, Li Z, Jia F, Sahni M, Wang $C$, Leung $K$, et al. Neuropathogenesis of chimeric simian/human immunodeficiency virus infection in pig-tailed and rhesus macaques. Brain Pathol. 1997;7:851-61.

72. Li JL, Zhuang $\mathrm{K}, \mathrm{Wu} \mathrm{GY}, \mathrm{Ho}$ WZ. Magnetic resonance imaging study of a simian/human immunodeficiency virus-infected Chinese rhesus macaque with HIV-associated dementia. AIDS Res Hum Retrovir. 2015;31:272-3.

73. Buch SJ, Villinger F, Pinson D, Hou Y, Adany I, Li Z, Dalal R, Raghavan R, Kumar A, Narayan O. Innate differences between simian-human immunodeficiency virus (SHIV)(KU-2)-infected rhesus and pig-tailed macaques in development of neurological disease. Virology. 2002;295:54-62

74. Toggas SM, Masliah E, Rockenstein EM, Rall GF, Abraham CR, Mucke L. Central nervous system damage produced by expression of the HIV-1 coat protein gp120 in transgenic mice. Nature. 1994;367:188-93.

75. Okamoto S, Kang YJ, Brechtel CW, Siviglia E, Russo R, Clemente A, Harrop A, McKercher S, Kaul M, Lipton SA. HIV/gp120 decreases adult neural progenitor cell proliferation via checkpoint kinase-mediated cell-cycle withdrawal and G1 arrest. Cell Stem Cell. 2007;1:230-6.

76. Lee MH, Wang $T$, Jang MH, Steiner J, Haughey $N$, Ming GL, Song H, Nath A, Venkatesan $\mathrm{A}$. Rescue of adult hippocampal neurogenesis in a mouse model of HIV neurologic disease. Neurobiol Dis. 2011;41:678-87.

77. D'hooge R, Franck F, Mucke L, De Deyn PP. Age-related behavioural deficits in transgenic mice expressing the HIV-1 coat protein gp120. Eur J Neurosci. 1999;11:4398-402

78. Kim BO, Liu Y, Ruan Y, Xu ZC, Schantz L, He JJ. Neuropathologies in transgenic mice expressing human immunodeficiency virus type 1 Tat protein under the regulation of the astrocyte-specific glial fibrillary acidic protein promoter and doxycycline. Am J Pathol. 2003;162:1693-707.

79. Bruce-Keller AJ, Turchan-Cholewo J, Smart EJ, Geurin T, Chauhan A, Reid R, Xu R, Nath A, Knapp PE, Hauser KF. Morphine causes rapid increases in glial activation and neuronal injury in the striatum of inducible HIV-1 Tat transgenic mice. Glia. 2008;56:1414-27.

80. Fitting S, Xu R, Bull C, Buch SK, El-Hage N, Nath A, Knapp PE, Hauser KF. Interactive comorbidity between opioid drug abuse and HIV-1 Tat: chronic exposure augments spine loss and sublethal dendritic pathology in striatal neurons. Am J Pathol. 2010;177:1397-410.

81. Fitting S, Ignatowska-Jankowska BM, Bull C, Skoff RP, Lichtman AH, Wise LE, Fox MA, Su J, Medina AE, Krahe TE, et al. Synaptic dysfunction in the hippocampus accompanies learning and memory deficits in human immunodeficiency virus type-1 Tat transgenic mice. Biol Psychiatry. 2013;73:443-53.

82. Carey AN, Sypek El, Singh HD, Kaufman MJ, McLaughlin JP. Expression of HIV-Tat protein is associated with learning and memory deficits in the mouse. Behav Brain Res. 2012;229:48-56.

83. Thomas FP, Chalk C, Lalonde R, Robitaille $Y$, Jolicoeur P. Expression of human immunodeficiency virus type 1 in the nervous system of transgenic mice leads to neurological disease. J Virol. 1994;68:7099-107.

84. Wang EJ, Sun J, Pettoello-Mantovani M, Anderson CM, Osiecki K, Zhao ML, Lopez L, Lee SC, Berman JW, Goldstein H. Microglia from mice transgenic for a provirus encoding a monocyte-tropic HIV type 1 isolate produce infectious virus and display in vitro and in vivo upregulation of lipopolysaccharide-induced chemokine gene expression. AIDS Res Hum Retrovir. 2003;19:755-65.

85. Santoro TJ, Bryant JL, Pellicoro J, Klotman ME, Kopp JB, Bruggeman LA, Franks RR, Notkins AL, Klotman PE. Growth failure and AIDS-like cachexia syndrome in HIV-1 transgenic mice. Virology. 1994;201:147-51. 
86. Sun J, Zheng JH, Zhao M, Lee S, Goldstein $\mathrm{H}$. Increased in vivo activation of microglia and astrocytes in the brains of mice transgenic for an infectious R5 human immunodeficiency virus type 1 provirus and for CD4-specific expression of human cyclin $\mathrm{T} 1$ in response to stimulation by lipopolysaccharides. J Virol. 2008;82:5562-72.

87. Reid W, Sadowska M, Denaro F, Rao S, Foulke J, Hayes N, Jones O, Doodnauth D, Davis H, Sill A, et al. An HIV-1 transgenic rat that develops HIV-related pathology and immunologic dysfunction. Proc Natl Acad Sci U S A. 2001;98:9271-6.

88. Peng J, Vigorito M, Liu X, Zhou D, Wu X, Chang SL. The HIV-1 transgenic rat as a model for HIV-1 infected individuals on HAART. J Neuroimmunol. 2010; 218:94-101.

89. Rao JS, Kim HW, Kellom M, Greenstein D, Chen M, Kraft AD, Harry GJ, Rapoport SI, Basselin M. Increased neuroinflammatory and arachidonic acid cascade markers, and reduced synaptic proteins, in brain of HIV-1 transgenic rats. J Neuroinflammation. 2011:8:101.

90. Lashomb AL, Vigorito M, Chang SL. Further characterization of the spatial learning deficit in the human immunodeficiency virus-1 transgenic rat. J Neuro-Oncol. 2009;15:14-24.

91. Vigorito M, LaShomb AL, Chang SL. Spatial learning and memory in HIV-1 transgenic rats. J Neurolmmune Pharmacol. 2007;2:319-28.

92. Reid WC, Casas R, Papadakis GZ, Muthusamy S, Lee DE, Ibrahim WG, Nair A, Koziol D, Maric D, Hammoud DA. Neurobehavioral abnormalities in the HIV1 transgenic rat do not correspond to neuronal Hypometabolism on 18FFDG-PET. PLoS One. 2016:11:e0152265.

93. Seay K, Qi X, Zheng JH, Zhang C, Chen K, Dutta M, Deneroff K, Ochsenbauer C, Kappes JC, Littman DR, Goldstein H. Mice transgenic for CD4-specific human CD4, CCR5 and cyclin T1 expression: a new model for investigating HIV-1 transmission and treatment efficacy. PLoS One. 2013;8:e63537.

94. Goffinet C, Allespach I, Keppler OT. HIV-susceptible transgenic rats allow rapid preclinical testing of antiviral compounds targeting virus entry or reverse transcription. Proc Natl Acad Sci U S A. 2007;104:1015-20.

95. Tervo HM, Goffinet C, Keppler OT. Mouse T-cells restrict replication of human immunodeficiency virus at the level of integration. Retrovirology. 2008;5:58

96. Potash MJ, Chao W, Bentsman G, Paris N, Saini M, Nitkiewicz J, Belem P, Sharer L, Brooks Al, Volsky DJ. A mouse model for study of systemic HIV-1 infection, antiviral immune responses, and neuroinvasiveness. Proc Natl Acad Sci U S A. 2005;102:3760-5

97. Hadas E, Chao W, He H, Saini M, Daley E, Saifuddin M, Bentsman G, Ganz E, Volsky DJ, Potash MJ. Transmission of chimeric HIV by mating in conventional mice: prevention by pre-exposure antiretroviral therapy and reduced susceptibility during estrus. Dis Model Mech. 2013;6:1292-8.

98. Kelschenbach JL, Saini M, Hadas E, Gu CJ, Chao W, Bentsman G, Hong JP, Hanke T, Sharer LR, Potash MJ, Volsky DJ. Mice chronically infected with chimeric HIV resist peripheral and brain superinfection: a model of protective immunity to HIV. J Neurolmmune Pharmacol. 2012;7:380-7.

99. Persidsky $Y$, Buttini M, Limoges J, Bock P, Gendelman HE. An analysis of HIV1 -associated inflammatory products in brain tissue of humans and SCID mice with HIV-1 encephalitis. J Neuro-Oncol. 1997;3:401-16.

100. Persidsky Y, Limoges J, McComb R, Bock P, Baldwin T, Tyor W, Patil A, Nottet HS, Epstein L, Gelbard H, et al. Human immunodeficiency virus encephalitis in SCID mice. Am J Pathol. 1996;149:1027-53.

101. Poluektova LY, Munn DH, Persidsky Y, Gendelman HE. Generation of cytotoxic T cells against virus-infected human brain macrophages in a murine model of HIV-1 encephalitis. J Immunol. 2002;168:3941-9.

102. Poluektova L, Gorantla S, Faraci J, Birusingh K, Dou H, Gendelman HE. Neuroregulatory events follow adaptive immune-mediated elimination of HIV-1-infected macrophages: studies in a murine model of viral encephalitis. J Immunol. 2004;172:7610-7.

103. Cook-Easterwood J, Middaugh LD, Griffin WC, Khan I, Tyor WR. Highly active antiretroviral therapy of cognitive dysfunction and neuronal abnormalities in SCID mice with HIV encephalitis. Exp Neurol. 2007;205: 506-12.

104. Rao VR, Sas AR, Eugenin EA, Siddappa NB, Bimonte-Nelson H, Berman JW, Ranga U, Tyor WR, Prasad VR. HIV-1 clade-specific differences in the induction of neuropathogenesis. J Neurosci. 2008;28:10010-6.

105. Traggiai E, Chicha L, Mazzucchelli L, Bronz L, Piffaretti JC, Lanzavecchia A, Manz MG. Development of a human adaptive immune system in cord blood cell-transplanted mice. Science. 2004;304:104-7.
106. Shultz LD, Lyons BL, Burzenski LM, Gott B, Chen X, Chaleff S, Kotb M, Gillies SD, King M, Mangada J, et al. Human lymphoid and myeloid cell development in NOD/LtSz-scid IL2R gamma null mice engrafted with mobilized human hemopoietic stem cells. J Immunol. 2005;174:6477-89.

107. Ito M, Hiramatsu H, Kobayashi K, Suzue K, Kawahata M, Hioki K, Ueyama Y, Koyanagi Y, Sugamura K, Tsuji K, et al. NOD/SCID/gamma(c)(null) mouse: an excellent recipient mouse model for engraftment of human cells. Blood. 2002;100:3175-82

108. Mosier DE, Gulizia RJ, Baird SM, Wilson DB. Transfer of a functional human immune system to mice with severe combined immunodeficiency. Nature. 1988;335:256-9.

109. Melkus MW, Estes JD, Padgett-Thomas A, Gatlin J, Denton PW, Othieno FA, Wege AK, Haase AT, Garcia JV. Humanized mice mount specific adaptive and innate immune responses to EBV and TSST-1. Nat Med. 2006;12:1316-22.

110. Hatziioannou T, Evans DT. Animal models for HIV/AIDS research. Nat Rev Microbiol. 2012;10:852-67.

111. Marsden MD, Zack JA. Studies of retroviral infection in humanized mice. Virology. 2015;479-480:297-309.

112. Dash PK, Gorantla S, Gendelman HE, Knibbe J, Casale GP, Makarov E, Epstein AA, Gelbard HA, Boska MD, Poluektova LY. Loss of neuronal integrity during progressive HIV-1 infection of humanized mice. J Neurosci. 2011;31:3148-57.

113. Boska MD, Dash PK, Knibbe J, Epstein AA, Akhter SP, Fields N, High R, Makarov E, Bonasera S, Gelbard HA, et al. Associations between brain microstructures, metabolites, and cognitive deficits during chronic HIV-1 infection of humanized mice. Mol Neurodegener. 2014;9:58.

114. Gorantla S, Makarov E, Finke-Dwyer J, Castanedo A, Holguin A, Gebhart CL, Gendelman HE, Poluektova L. Links between progressive HIV-1 infection of humanized mice and viral neuropathogenesis. Am J Pathol. 2010;177: 2938-49.

115. Kim HJ, Shin AH, Thayer SA. Activation of Cannabinoid type 2 receptors inhibits HIV-1 envelope glycoprotein gp120-induced synapse loss. Mol Pharmacol. 2011;80:357-66.

116. Kim HJ, Martemyanov KA, Thayer SA. Human immunodeficiency virus protein Tat induces synapse loss via a reversible process that is distinct from cell death. J Neurosci. 2008;28:12604-13.

117. Shin AH, Thayer SA. Human immunodeficiency virus-1 protein Tat induces excitotoxic loss of presynaptic terminals in hippocampal cultures. Mol Cell Neurosci. 2013;54:22-9.

118. Shin AH, Kim HJ, Thayer SA. Subtype selective NMDA receptor antagonists induce recovery of synapses lost following exposure to HIV-1 Tat. $\mathrm{Br}$ J Pharmacol. 2012;166:1002-17.

119. Iskander S, Walsh KA, Hammond RR. Human CNS cultures exposed to HIV-1 gp120 reproduce dendritic injuries of HIV-1-associated dementia. J Neuroinflammation. 2004;1:7.

120. Choi DW. Excitotoxic cell death. J Neurobiol. 1992;23:1261-76.

121. Fontana G, Valenti L, Raiteri M. Gp120 can revert antagonism at the glycine site of NMDA receptors mediating GABA release from cultured hippocampal neurons. J Neurosci Res. 1997:49:732-8.

122. Xu H, Bae M, Tovar-y-Romo LB, Patel N, Bandaru W, Pomerantz D, Steiner JP, Haughey NJ. The human immunodeficiency virus coat protein gp120 promotes forward trafficking and surface clustering of NMDA receptors in membrane microdomains. J Neurosci. 2011;31:17074-90.

123. Lavi E, Strizki JM, Ulrich AM, Zhang W, Fu L, Wang Q, O'Connor M, Hoxie JA, González-Scarano F. CXCR-4 (Fusin), a co-receptor for the type 1 human immunodeficiency virus (HIV-1), is expressed in the human brain in a variety of cell types, including microglia and neurons. Am J Pathol. 1997; 151:1035-42.

124. Rottman JB, Ganley KP, Williams K, Wu L, Mackay CR, Ringler DJ. Cellular localization of the chemokine receptor CCR5. Correlation to cellular targets of HIV-1 infection. Am J Pathol. 1997;151:1341-51.

125. Alkhatib G, Combadiere C, Broder CC, Feng Y, Kennedy PE, Murphy PM, Berger EA. CC CKR5: a RANTES, MIP-1alpha, MIP-1beta receptor as a fusion cofactor for macrophage-tropic HIV-1. Science. 1996;272:1955-8.

126. Choe H, Farzan M, Sun Y, Sullivan N, Rollins B, Ponath PD, Wu L, Mackay CR, LaRosa G, Newman W, et al. The beta-chemokine receptors CCR3 and CCR5 facilitate infection by primary HIV-1 isolates. Cell. 1996;85:1135-48.

127. Dragic T, Litwin V, Allaway GP, Martin SR, Huang Y, Nagashima KA, Cayanan C, Maddon PJ, Koup RA, Moore JP, Paxton WA. HIV-1 entry into CD4+ cells is mediated by the chemokine receptor CC-CKR-5. Nature. 1996;381:667-73. 
128. Feng Y, Broder CC, Kennedy PE, Berger EA. HIV-1 entry cofactor: functional cDNA cloning of a seven-transmembrane, $\mathrm{G}$ protein-coupled receptor. Science. 1996;272:872-7.

129. Marchionni I, Beaumont M, Maccaferri G. The chemokine CXCL12 and the HIV-1 envelope protein gp120 regulate spontaneous activity of Cajal-Retzius cells in opposite directions. J Physiol. 2012;590:3185-202.

130. Catani MV, Corasaniti MT, Navarra M, Nisticò G, Finazzi-Agrò A, Melino G. gp120 induces cell death in human neuroblastoma cells through the CXCR4 and CCR5 chemokine receptors. J Neurochem. 2000;74: 2373-9.

131. Ru W, Tang SJ. HIV-1 gp120Bal down-regulates Phosphorylated NMDA receptor subunit 1 in cortical neurons via activation of glutamate and chemokine receptors. J Neurolmmune Pharmacol. 2016;11:182-91.

132. Maung R, Hoefer MM, Sanchez AB, Sejbuk NE, Medders KE, Desai MK, Catalan IC, Dowling CC, de Rozieres CM, Garden GA, et al. CCR5 knockout prevents neuronal injury and behavioral impairment induced in a transgenic mouse model by a CXCR4-using HIV-1 glycoprotein 120. J Immunol. 2014;193:1895-910.

133. Kaul M, Garden GA, Lipton SA. Pathways to neuronal injury and apoptosis in HIV-associated dementia. Nature. 2001;410:988-94.

134. Nicolai J, Burbassi S, Rubin J, Meucci O. CXCL12 inhibits expression of the NMDA receptor's NR2B subunit through a histone deacetylasedependent pathway contributing to neuronal survival. Cell Death Dis. 2010;1:e33.

135. Medders KE, Sejbuk NE, Maung R, Desai MK, Kaul M. Activation of p38 MAPK is required in monocytic and neuronal cells for HIV glycoprotein 120induced neurotoxicity. J Immunol. 2010;185:4883-95.

136. Garden GA, Guo W, Jayadev S, Tun C, Balcaitis S, Choi J, Montine TJ, Möller T, Morrison RS. HIV associated neurodegeneration requires p53 in neurons and microglia. FASEB J. 2004;18:1141-3.

137. Lazarini F, Casanova P, Tham TN, De Clercq E, Arenzana-Seisdedos F, Baleux F, Dubois-Dalcq M. Differential signalling of the chemokine receptor CXCR4 by stromal cell-derived factor 1 and the HIV glycoprotein in rat neurons and astrocytes. Eur J Neurosci. 2000;12:117-25.

138. Viviani B, Gardoni F, Bartesaghi S, Corsini E, Facchi A, Galli CL, Di Luca M, Marinovich M. Interleukin-1 beta released by gp120 drives neural death through tyrosine phosphorylation and trafficking of NMDA receptors. J Biol Chem. 2006;281:30212-22.

139. Brabers NA, Nottet HS. Role of the pro-inflammatory cytokines TNFalpha and IL-1beta in HIV-associated dementia. Eur J Clin Investig. 2006; 36:447-58.

140. Melendez RI, Roman C, Capo-Velez CM, Lasalde-Dominicci JA. Decreased glial and synaptic glutamate uptake in the striatum of HIV-1 gp120 transgenic mice. J Neuro-Oncol. 2015;22:358-65.

141. Dreyer EB, Lipton SA. The coat protein gp120 of HIV-1 inhibits astrocyte uptake of excitatory amino acids via macrophage arachidonic acid. Eur Neurosci. 1995;7:2502-7.

142. Vázquez-Santiago FJ, Noel RJ, Porter JT, Rivera-Amill V. Glutamate metabolism and HIV-associated neurocognitive disorders. J Neuro-Oncol. 2014;20:315-31.

143. Potter MC, Figuera-Losada M, Rojas C, Slusher BS. Targeting the glutamatergic system for the treatment of HIV-associated neurocognitive disorders. J Neurolmmune Pharmacol. 2013:8:594-607.

144. Bachis A, Major EO, Mocchetti I. Brain-derived neurotrophic factor inhibits human immunodeficiency virus-1/gp120-mediated cerebellar granule cell death by preventing gp120 internalization. J Neurosci. 2003;23:5715-22.

145. Nosheny RL, Bachis A, Acquas E, Mocchetti I. Human immunodeficiency virus type 1 glycoprotein gp120 reduces the levels of brain-derived neurotrophic factor in vivo: potential implication for neuronal cell death. Eur J Neurosci. 2004;20:2857-64.

146. Mocchetti I, Nosheny RL, Tanda G, Ren K, Meyer EM. Brain-derived neurotrophic factor prevents human immunodeficiency virus type 1 protein gp120 neurotoxicity in the rat nigrostriatal system. Ann N Y Acad Sci. 2007; 1122:144-54.

147. Viviani B, Corsini E, Binaglia M, Galli CL, Marinovich M. Reactive oxygen species generated by glia are responsible for neuron death induced by human immunodeficiency virus-glycoprotein 120 in vitro. Neuroscience. 2001;107:51-8.

148. Kaul M, Lipton SA. Chemokines and activated macrophages in HIV gp120-induced neuronal apoptosis. Proc Natl Acad Sci U S A. 1999;96: 8212-6.
149. Self RL, Mulholland PJ, Nath A, Harris BR, Prendergast MA. The human immunodeficiency virus type-1 transcription factor Tat produces elevations in intracellular Ca2+ that require function of an N-methyl-D-aspartate receptor polyamine-sensitive site. Brain Res. 2004;995:39-45.

150. Haughey NJ, Holden CP, Nath A, Geiger JD. Involvement of inositol 1,4,5trisphosphate-regulated stores of intracellular calcium in calcium dysregulation and neuron cell death caused by HIV-1 protein Tat. J Neurochem. 1999;73:1363-74.

151. Li W, Huang Y, Reid R, Steiner J, Malpica-Llanos T, Darden TA, Shankar SK, Mahadevan A, Satishchandra P, Nath A. NMDA receptor activation by HIVTat protein is clade dependent. J Neurosci. 2008:28:12190-8.

152. Perry SW, Norman JP, Litzburg A, Zhang D, Dewhurst S, Gelbard HA. HIV-1 transactivator of transcription protein induces mitochondrial hyperpolarization and synaptic stress leading to apoptosis. J Immunol. 2005; 174:4333-44.

153. Rappaport J, Joseph J, Croul S, Alexander G, Del Valle L, Amini S, Khalili K. Molecular pathway involved in HIV-1-induced CNS pathology: role of viral regulatory protein, Tat. J Leukoc Biol. 1999;65:458-65.

154. Liu Y, Jones M, Hingtgen CM, Bu G, Laribee N, Tanzi RE, Moir RD, Nath A, He JJ. Uptake of HIV-1 Tat protein mediated by low-density lipoprotein receptor-related protein disrupts the neuronal metabolic balance of the receptor ligands. Nat Med. 2000;6:1380-7.

155. Aksenov MY, Hasselrot U, Bansal AK, Wu G, Nath A, Anderson C, Mactutus CF, Booze RM. Oxidative damage induced by the injection of HIV-1 Tat protein in the rat striatum. Neurosci Lett. 2001;305:5-8.

156. Nath A, Conant K, Chen P, Scott C, Major EO. Transient exposure to HIV-1 Tat protein results in cytokine production in macrophages and astrocytes. A hit and run phenomenon. J Biol Chem. 1999:274:17098-102.

157. Jin J, Lam L, Sadic E, Fernandez F, Tan J, Giunta B. HIV-1 Tat-induced microglial activation and neuronal damage is inhibited via CD45 modulation: a potential new treatment target for HAND. Am J Transl Res. 2012:4:302-15.

158. Bokhari SM, Yao H, Bethel-Brown C, Fuwang P, Williams R, Dhillon NK, Hegde R, Kumar A, Buch SJ. Morphine enhances Tat-induced activation in murine microglia. J Neuro-Oncol. 2009;15:219-28.

159. Haase AT. Pathogenesis of lentivirus infections. Nature. 1986:322:130-6.

160. Argyris EG, Acheampong E, Nunnari G, Mukhtar M, Williams KJ, Pomerantz RJ. Human immunodeficiency virus type 1 enters primary human brain microvascular endothelial cells by a mechanism involving cell surface proteoglycans independent of lipid rafts. J Virol. 2003;77:12140-51.

161. Mankowski JL, Spelman JP, Ressetar HG, Strandberg JD, Laterra J, Carter DL, Clements JE, Zink MC. Neurovirulent simian immunodeficiency virus replicates productively in endothelial cells of the central nervous system in vivo and in vitro. J Virol. 1994;68:8202-8.

162. Bobardt MD, Salmon P, Wang L, Esko JD, Gabuzda D, Fiala M, Trono D, Van der Schueren B, David G, Gallay PA. Contribution of proteoglycans to human immunodeficiency virus type 1 brain invasion. J Virol. 2004; 78:6567-84

163. Liu NQ, Lossinsky AS, Popik W, Li X, Gujuluva C, Kriederman B, Roberts J, Pushkarsky T, Bukrinsky M, Witte $M$, et al. Human immunodeficiency virus type 1 enters brain microvascular endothelia by macropinocytosis dependent on lipid rafts and the mitogen-activated protein kinase signaling pathway. J Virol. 2002;76:6689-700.

164. Bomsel M. Transcytosis of infectious human immunodeficiency virus across a tight human epithelial cell line barrier. Nat Med. 1997;3:42-7.

165. Strazza M, Pirrone V, Wigdahl B, Nonnemacher MR. Breaking down the barrier: the effects of HIV-1 on the blood-brain barrier. Brain Res. 2011; 1399:96-115.

166. Eugenin EA, Clements JE, Zink MC, Berman JW. Human immunodeficiency virus infection of human astrocytes disrupts bloodbrain barrier integrity by a gap junction-dependent mechanism. J Neurosci. 2011:31:9456-65.

167. Saha RN, Pahan K. Tumor necrosis factor-alpha at the crossroads of neuronal life and death during HIV-associated dementia. J Neurochem. 2003;86:1057-71.

168. Shah A, Verma AS, Patel KH, Noel R, Rivera-Amill V, Silverstein PS, Chaudhary S, Bhat HK, Stamatatos L, Singh DP, et al. HIV-1 gp120 induces expression of IL-6 through a nuclear factor-kappa B-dependent mechanism: suppression by gp120 specific small interfering RNA. PLoS One. 2011;6:e21261.

169. Ellis RJ, Calero P, Stockin MD. HIV infection and the central nervous system: a primer. Neuropsychol Rev. 2009;19:144-51. 
170. Orandle MS, MacLean AG, Sasseville VG, Alvarez X, Lackner AA. Enhanced expression of proinflammatory cytokines in the central nervous system is associated with neuroinvasion by simian immunodeficiency virus and the development of encephalitis. J Virol. 2002;76:5797-802.

171. Cinque P, Brew BJ, Gisslen M, Hagberg L, Price RW. Cerebrospinal fluid markers in central nervous system HIV infection and AIDS dementia complex. Handb Clin Neurol. 2007;85:261-300.

172. Bandaru W, McArthur JC, Sacktor N, Cutler RG, Knapp EL, Mattson MP, Haughey NJ. Associative and predictive biomarkers of dementia in HIV-1infected patients. Neurology. 2007;68:1481-7.

173. Yuan L, Qiao L, Wei F, Yin J, Liu L, Ji Y, Smith D, Li N, Chen D. Cytokines in CSF correlate with HIV-associated neurocognitive disorders in the postHAART era in China. J Neuro-Oncol. 2013;19:144-9.

174. Yeh MW, Kaul M, Zheng J, Nottet HS, Thylin M, Gendelman HE, Lipton SA. Cytokine-stimulated, but not HIV-infected, human monocyte-derived macrophages produce neurotoxic levels of I -cysteine. J Immunol. 2000;164: 4265-70.

175. Kaul M, Zheng J, Okamoto S, Gendelman HE, Lipton SA. HIV-1 infection and AIDS: consequences for the central nervous system. Cell Death Differ. 2005; 12(Suppl 1):878-92.

176. Kovalevich J, Langford D. Neuronal toxicity in HIV CNS disease. Future Virol. 2012;7:687-98

177. Khairova RA, Machado-Vieira R, Du J, Manji HK. A potential role for proinflammatory cytokines in regulating synaptic plasticity in major depressive disorder. Int J Neuropsychopharmacol. 2009;12:561-78.

178. Olmos G, Lladó J. Tumor necrosis factor alpha: a link between neuroinflammation and excitotoxicity. Mediat Inflamm. 2014;2014: 861231.

179. Peng H, Erdmann N, Whitney N, Dou H, Gorantla S, Gendelman HE, Ghorpade A, Zheng J. HIV-1-infected and/or immune activated macrophages regulate astrocyte SDF-1 production through IL-1beta. Glia. 2006:54:619-29.

180. Rostasy K, Egles C, Chauhan A, Kneissl M, Bahrani P, Yiannoutsos C, Hunter DD, Nath A, Hedreen JC, Navia BA. SDF-1alpha is expressed in astrocytes and neurons in the AIDS dementia complex: an in vivo and in vitro study. J Neuropathol Exp Neurol. 2003:62:617-26.

181. Zheng J, Thylin MR, Ghorpade A, Xiong H, Persidsky Y, Cotter R, Niemann D, Che M, Zeng YC, Gelbard HA, et al. Intracellular CXCR4 signaling, neuronal apoptosis and neuropathogenic mechanisms of HIV-1-associated dementia. J Neuroimmunol. 1999:98:185-200.

182. Khan MZ, Brandimarti R, Shimizu S, Nicolai J, Crowe E, Meucci O. The chemokine CXCL12 promotes survival of postmitotic neurons by regulating Rb protein. Cell Death Differ. 2008;15:1663-72.

183. Vergote D, Butler GS, Ooms M, Cox JH, Silva C, Hollenberg MD, Jhamandas $\mathrm{JH}$, Overall CM, Power C. Proteolytic processing of SDF-1alpha reveals a change in receptor specificity mediating HIV-associated neurodegeneration. Proc Natl Acad Sci U S A. 2006:103:19182-7.

184. Sui Y, Stehno-Bittel L, Li S, Loganathan R, Dhillon NK, Pinson D, Nath A, Kolson D, Narayan O, Buch S. CXCL10-induced cell death in neurons: role of calcium dysregulation. Eur J Neurosci. 2006;23:957-64.

185. Sui Y, Potula R, Dhillon N, Pinson D, Li S, Nath A, Anderson C, Turchan J, Kolson D, Narayan O, Buch S. Neuronal apoptosis is mediated by CXCL10 overexpression in simian human immunodeficiency virus encephalitis. Am J Pathol. 2004;164:1557-66.

186. Sui Y, Li S, Pinson D, Adany I, Li Z, Villinger F, Narayan O, Buch S. Simian human immunodeficiency virus-associated pneumonia correlates with increased expression of MCP-1, CXCL10, and viral RNA in the lungs of rhesus macaques. Am J Pathol. 2005;166:355-65.

187. Kelder W, McArthur JC, Nance-Sproson T, McClernon D, Griffin DE. Betachemokines MCP-1 and RANTES are selectively increased in cerebrospinal fluid of patients with human immunodeficiency virus-associated dementia. Ann Neurol. 1998:44:831-5.

188. Deshmane SL, Kremlev S, Amini S, Sawaya BE. Monocyte chemoattractant protein-1 (MCP-1): an overview. J Interf Cytokine Res. 2009;29:313-26.

189. Ragin AB, Wu Y, Storey P, Cohen BA, Edelman RR, Epstein LG. Monocyte chemoattractant protein-1 correlates with subcortical brain injury in HIV infection. Neurology. 2006;66:1255-7.

190. Sevigny JJ, Albert SM, McDermott MP, MCArthur JC, Sacktor N, Conant K Schifitto G, Selnes OA, Stern Y, McClernon DR, et al. Evaluation of HIV RNA and markers of immune activation as predictors of HIV-associated dementia. Neurology. 2004;63:2084-90.
191. Sevigny JJ, Albert SM, McDermott MP, Schifitto G, McArthur JC, Sacktor N, Conant K, Selnes OA, Stern Y, McClernon DR, et al. An evaluation of neurocognitive status and markers of immune activation as predictors of time to death in advanced HIV infection. Arch Neurol. 2007:64:97-102.

192. Letendre SL, Zheng JC, Kaul M, Yiannoutsos CT, Ellis RJ, Taylor MJ, MarquieBeck J, Navia B, Consortium HN. Chemokines in cerebrospinal fluid correlate with cerebral metabolite patterns in HIV-infected individuals. J Neuro-Oncol. 2011;17:63-9.

193. Sporer B, Kastenbauer S, Koedel U, Arendt G, Pfister HW. Increased intrathecal release of soluble fractalkine in HIV-infected patients. AIDS Res Hum Retrovir. 2003:19:111-6.

194. Foussat A, Bouchet-Delbos L, Berrebi D, Durand-Gasselin I, CoulombL'Hermine A, Krzysiek R, Galanaud P, Levy Y, Emilie D. Deregulation of the expression of the fractalkine/fractalkine receptor complex in HIV-1-infected patients. Blood. 2001;98:1678-86.

195. Tong N, Perry SW, Zhang Q, James HJ, Guo H, Brooks A, Bal H, Kinnear SA, Fine S, Epstein LG, et al. Neuronal fractalkine expression in HIV-1 encephalitis: roles for macrophage recruitment and neuroprotection in the central nervous system. J Immunol. 2000;164:1333-9.

196. Pereira CF, Middel J, Jansen G, Verhoef J, Nottet HS. Enhanced expression of fractalkine in HIV-1 associated dementia. J Neuroimmunol. 2001;115:168-75.

197. Cotter R, Williams C, Ryan L, Erichsen D, Lopez A, Peng H, Zheng J. Fractalkine (CX3CL1) and brain inflammation: implications for HIV-1associated dementia. J Neuro-Oncol. 2002;8:585-98.

198. Erichsen D, Lopez AL, Peng H, Niemann D, Williams C, Bauer M, Morgello S, Cotter RL, Ryan LA, Ghorpade A, et al. Neuronal injury regulates fractalkine: relevance for HIV-1 associated dementia. J Neuroimmunol. 2003;138:144-55.

199. Noda M, Doi Y, Liang J, Kawanokuchi J, Sonobe Y, Takeuchi H, Mizuno T, Suzumura A. Fractalkine attenuates excito-neurotoxicity via microglial clearance of damaged neurons and antioxidant enzyme heme oxygenase-1 expression. J Biol Chem. 2011;286:2308-19.

200. Limatola C, Lauro C, Catalano M, Ciotti MT, Bertollini C, Di Angelantonio S, Ragozzino D, Eusebi F. Chemokine CX3CL1 protects rat hippocampal neurons against glutamate-mediated excitotoxicity. J Neuroimmunol. 2005; 166:19-28.

201. Suzuki M, El-Hage N, Zou S, Hahn YK, Sorrell ME, Sturgill JL, Conrad DH, Knapp PE, Hauser KF. Fractalkine/CX3CL1 protects striatal neurons from synergistic morphine and HIV-1 Tat-induced dendritic losses and death. Mol Neurodegener. 2011;6:78

202. Giulian D, Vaca K, Noonan CA. Secretion of neurotoxins by mononuclear phagocytes infected with HIV-1. Science. 1990;250:1593-6.

203. Tian C, Sun L, Jia B, Ma K, Curthoys N, Ding J, Zheng J. Mitochondrial glutaminase release contributes to glutamate-mediated neurotoxicity during human immunodeficiency virus-1 infection. J Neurolmmune Pharmacol. 2012;7:619-28.

204. Perry SW, Hamilton JA, Tjoelker LW, Dbaibo G, Dzenko KA, Epstein LG, Hannun Y, Whittaker JS, Dewhurst S, Gelbard HA. Platelet-activating factor receptor activation. An initiator step in HIV-1 neuropathogenesis. J Biol Chem. 1998:273:17660-4.

205. Sacktor N, Haughey N, Cutler R, Tamara A, Turchan J, Pardo C, Vargas D, Nath A. Novel markers of oxidative stress in actively progressive HIV dementia. J Neuroimmunol. 2004;157:176-84.

206. Turchan J, Pocernich CB, Gairola C, Chauhan A, Schifitto G, Butterfield DA, Buch S, Narayan O, Sinai A, Geiger J, et al. Oxidative stress in HIV demented patients and protection ex vivo with novel antioxidants. Neurology. 2003;60:307-14

207. Boche D, Perry VH, Nicoll JA. Review: activation patterns of microglia and their identification in the human brain. Neuropathol Appl Neurobiol. 2013; 39:3-18.

208. Colton CA. Heterogeneity of microglial activation in the innate immune response in the brain. J Neurolmmune Pharmacol. 2009;4:399-418.

209. Edwards JP, Zhang X, Frauwirth KA, Mosser DM. Biochemical and functional characterization of three activated macrophage populations. J Leukoc Biol. 2006;80:1298-307.

210. Tang $Y$, Le W. Differential roles of $M 1$ and $M 2$ microglia in neurodegenerative diseases. Mol Neurobiol. 2016;53:1181-94.

211. Conant K, Tornatore C, Atwood W, Meyers K, Traub R, Major EO. In vivo and in vitro infection of the astrocyte by HIV-1. Adv Neuroimmunol. 1994;4:287-9.

212. Tornatore C, Chandra R, Berger JR, Major EO. HIV-1 infection of subcortical astrocytes in the pediatric central nervous system. Neurology. 1994;44: $481-7$. 
213. Gorry PR, Ong C, Thorpe J, Bannwarth S, Thompson KA, Gatignol A, Vesselingh SL, Purcell DF. Astrocyte infection by HIV-1: mechanisms of restricted virus replication, and role in the pathogenesis of HIV-1-associated dementia. Curr HIV Res. 2003;1:463-73.

214. Churchill MJ, Gorry PR, Cowley D, Lal L, Sonza S, Purcell DF, Thompson KA, Gabuzda D, McArthur JC, Pardo CA, Wesselingh SL. Use of laser capture microdissection to detect integrated HIV-1 DNA in macrophages and astrocytes from autopsy brain tissues. J Neuro-Oncol. 2006;12:146-52.

215. Ton $\mathrm{H}$, Xiong H. Astrocyte dysfunctions and HIV-1 neurotoxicity. J AIDS Clin Res. 2013:4:255.

216. Ranki A, Nyberg M, Ovod V, Haltia M, Elovaara I, Raininko R, Haapasalo H, Krohn K. Abundant expression of HIV Nef and Rev proteins in brain astrocytes in vivo is associated with dementia. AIDS. 1995;9:1001-8.

217. Gorry P, Purcell D, Howard J, McPhee D. Restricted HIV-1 infection of human astrocytes: potential role of nef in the regulation of virus replication. J Neuro-Oncol. 1998;4:377-86.

218. Nath A. Human immunodeficiency virus (HIV) proteins in neuropathogenesis of HIV dementia. J Infect Dis. 2002;186(Suppl 2):S193-8.

219. Chompre G, Cruz E, Maldonado L, Rivera-Amill V, Porter JT, Noel RJ. Astrocytic expression of HIV-1 Nef impairs spatial and recognition memory. Neurobiol Dis. 2013:49:128-36.

220. Nottet HS, Jett M, Flanagan CR, Zhai QH, Persidsky Y, Rizzino A, Bernton EW, Genis $\mathrm{P}$, Baldwin T, Schwartz J. A regulatory role for astrocytes in HIV-1 encephalitis. An overexpression of eicosanoids, platelet-activating factor, and tumor necrosis factor-alpha by activated HIV-1-infected monocytes is attenuated by primary human astrocytes. J Immunol. 1995;154:3567-81.

221. Shah A, Singh DP, Buch S, Kumar A. HIV-1 envelope protein gp120 up regulates CCL5 production in astrocytes which can be circumvented by inhibitors of NF-KB pathway. Biochem Biophys Res Commun. 2011;414:112-7.

222. Reddy PV, Gandhi N, Samikkannu T, Saiyed Z, Agudelo M, Yndart A, Khatavkar P, Nair MP. HIV-1 gp120 induces antioxidant response elementmediated expression in primary astrocytes: role in HIV associated neurocognitive disorder. Neurochem Int. 2012;61:807-14.

223. Eugenin EA, Berman JW. Gap junctions mediate human immunodeficiency virus-bystander killing in astrocytes. J Neurosci. 2007;27:12844-50.

224. Wang Z, Pekarskaya O, Bencheikh M, Chao W, Gelbard HA, Ghorpade A, Rothstein JD, Volsky DJ. Reduced expression of glutamate transporter EAAT2 and impaired glutamate transport in human primary astrocytes exposed to HIV-1 or gp120. Virology. 2003;312:60-73.

225. Patton HK, Zhou ZH, Bubien JK, Benveniste EN, Benos DJ. gp120-induced alterations of human astrocyte function: $\mathrm{Na}(+) / \mathrm{H}(+)$ exchange, $\mathrm{K}(+)$ conductance, and glutamate flux. Am J Physiol Cell Physiol. 2000;279:C700-8.

226. Zhou BY, Liu Y, Kim B, Xiao Y, He JJ. Astrocyte activation and dysfunction and neuron death by HIV-1 Tat expression in astrocytes. Mol Cell Neurosci. 2004;27:296-305.

227. Brown GC, Neher JJ. Microglial phagocytosis of live neurons. Nat Rev Neurosci. 2014;15:209-16.

228. Xavier AL, Menezes JR, Goldman SA, Nedergaard M. Fine-tuning the central nervous system: microglial modelling of cells and synapses. Philos Trans $R$ Soc Lond Ser B Biol Sci. 2014;369:20130593.

229. Schafer DP, Lehrman EK, Kautzman AG, Koyama R, Mardinly AR, Yamasaki R, Ransohoff RM, Greenberg ME, Barres BA, Stevens B. Microglia sculpt postnatal neural circuits in an activity and complement-dependent manner. Neuron. 2012;74:691-705.

230. Stevens B, Allen NJ, Vazquez LE, Howell GR, Christopherson KS, Nouri N, Micheva KD, Mehalow AK, Huberman AD, Stafford B, et al. The classical complement cascade mediates CNS synapse elimination. Cell. 2007;131:1164-78.

231. Hong S, Beja-Glasser VF, Nfonoyim BM, Frouin A, Li S, Ramakrishnan S, Merry KM, Shi Q, Rosenthal A, Barres BA, et al. Complement and microglia mediate early synapse loss in Alzheimer mouse models. Science. 2016;352:712-6.

232. Vasek MJ, Garber C, Dorsey D, Durrant DM, Bollman B, Soung A, Yu J, PerezTorres C, Frouin A, Wilton DK, et al. A complement-microglial axis drives synapse loss during virus-induced memory impairment. Nature. 2016;534: 538-43.

233. Liu F, Dai S, Gordon J, Qin X. Complement and HIV-I infection/HIVassociated neurocognitive disorders. J Neuro-Oncol. 2014;20:184-98,

234. Yu Q, Yu R, Qin X. The good and evil of complement activation in HIV-1 infection. Cell Mol Immunol. 2010;7:334-40.

235. McGuire JL, Gill AJ, Douglas SD, Kolson DL, Group CHATERC. The complement system, neuronal injury, and cognitive function in horizontallyacquired HIV-infected youth. J Neuro-Oncol. 2016;22:823-30.
236. Blomster LV, Vukovic J, Hendrickx DA, Jung S, Harvey AR, Filgueira L, Ruitenberg MJ. CX ${ }_{3} C R 1$ deficiency exacerbates neuronal loss and impairs early regenerative responses in the target-ablated olfactory epithelium. Mol Cell Neurosci. 2011:48:236-45.

237. Fuhrmann M, Bittner T, Jung CK, Burgold S, Page RM, Mitteregger G, Haass C, LaFerla FM, Kretzschmar H, Herms J. Microglial Cx3cr1 knockout prevents neuron loss in a mouse model of Alzheimer's disease. Nat Neurosci. 2010;13: 411-3.

238. Zabel MK, Zhao L, Zhang Y, Gonzalez SR, Ma W, Wang X, Fariss RN, Wong WT. Microglial phagocytosis and activation underlying photoreceptor degeneration is regulated by CX3CL1-CX3CR1 signaling in a mouse model of retinitis pigmentosa. Glia. 2016;64:1479-91.

239. Chung WS, Clarke LE, Wang GX, Stafford BK, Sher A, Chakraborty C, Joung J, Foo LC, Thompson A, Chen C, et al. Astrocytes mediate synapse elimination through MEGF10 and MERTK pathways. Nature. 2013;504:394-400.

240. Chung WS, Allen NJ, Eroglu C. Astrocytes control synapse formation, function, and elimination. Cold Spring Harb Perspect Biol. 2015;7:a020370.

241. Chung WS, Welsh CA, Barres BA, Stevens B. Do glia drive synaptic and cognitive impairment in disease? Nat Neurosci. 2015;18:1539-45.

242. Chung WS, Verghese PB, Chakraborty C, Joung J, Hyman BT, Ulrich JD, Holtzman DM, Barres BA. Novel allele-dependent role for APOE in controlling the rate of synapse pruning by astrocytes. Proc Natl Acad Sci U S A. 2016;113:10186-91.

\section{Submit your next manuscript to BioMed Central and we will help you at every step:}

- We accept pre-submission inquiries

- Our selector tool helps you to find the most relevant journal

- We provide round the clock customer support

- Convenient online submission

- Thorough peer review

- Inclusion in PubMed and all major indexing services

- Maximum visibility for your research

Submit your manuscript at www.biomedcentral.com/submit
( Biomed Central 